\title{
A EVOLUÇÃO DA PESQUISA EM FORRAGICULTURA E PASTAGENS NO BRASIL
}

\author{
G.L.da Rocha*
}

\section{INTRODUÇÃO}

A vegetação do Brasil quando da chegada do homem branco no final do século XV era caracterizada em sua grande maioria por formações florestais. Estas, em suas diferentes manifestações climax, perfaziam cerca de $89 \%$ do território nacional, assim divididas: florestas $61 \%$ (equatorial, tropical e subtropical), cerrado $20 \%$ e caatingas $8 \%$; os restantes $10 \%$ aproximadamente, eram ocupa dos com formações campestres (39).

Os campos mais representativos se concentram na Região Sul do Brasil com domínio ecológico de capins, contando em sua composição florística leguminosas de valor forrageiro. A área "pronta para o pastejo" nesse extremo meridional do país soma cerca de $154.000 \mathrm{~km}^{2}(26)$ ou aproximadamente $17 \%$ das formações campestres nacionais. As demais superfícies de mesma categoria vegetal são os "campos de altitude", "campos inundāveis" e "complexo do pantanal" (10).

Outras āreas de pastejo são de origem antrópica, dependentes da atuação do homem e seus animais. Pela ação do fogo e "pisoteio/pastejo" sobre as formações florestais mais abertas como a caatinga e o cerrado, instalaramrse progressivamente os "campos", uma expressão

*Bolsista do CNPq.

Pesquisador Científico - Inst. de Zootecnia. 
de climax biótico ou um sub-climax, mantido pelo pasto combinado com queimas repetidas ou eventuais.

0 estabelecimento de pastagens nas äreas de floresta iniciou-se praticamente no começo deste século e se intensificou a partir das décadas de 30 e 40 . A derrubada da mata visava o preparo da terra, a médio e longo prazos, para ser utilizada com os cultivos anuais - milho, algodão, etc. - e principalmente para a formação de cafezais nas melhores glebas.

Dentro dessa projeção da agricultura, o boi seria o elemento desbravador nas fases iniciais de substituição das densas florestas por cultivos de consumo e exportação. Na falta de um comércio organizado de venda de sementes, o plantio do capim nas áreas derrubadas e queimadas se fazia por via vegetativa. Mudas eram plantadas, sobre as cinzas, desde $12 \times 12 \mathrm{~m}$ até, mais usualmente de $2 \times 2 \mathrm{~m}$, em função da disponibilidade de viveiros da gramínea a ser cultivada. Nas regiōes onde a pecuária parecia ser um empreendimento de futuro economicamente promissor, os pecuaristas iniciantes ado tavam o plantio de mudas nos menores compassos.

Esse sistema de formação de invernadas estava de acordo com as condições econômicas da época, em que a mão-de-obra disponivel e barata, favorecia o avanço do empreendimento sobre extensas áreas. Com grande frequência o plantio das mudas mais espaçadas permitia intercalar o cultivo de cereais de subsistência. No segundo ano as sementes do capim caídas ao solo asseguravam o estabelecimento da invernada.

Quando se iniciava, após a queimada, a ocupação da ärea com agricultura anual (milho, arroz, feijao, etc.) o capim era semeado nos espaços entre as plantas, cerca de 30 a 40 dias mais tarde. Com a sombra parcial as plântulas se defendiam melhor das chuvas pesadas e excesso de insolação. A medida que o milho ( $p$. ex.) amadurecia em $j$ aneiro/fevereiro, as plantas reduziam sua sombra assegurando maior velocidade de crescimento do pasto. 
Desenvolveu-se nessas condições, empiricamente, a primeira inovação tecnológica, embora rudimentar, de se adotar uma "planta companheira" ou "planta de meia sombra" para assegurar um microclima favorävel à germinação das sementes.

As formas de contrato para as derrubadas previam, normalmente, autorização para o cultivo de cereais por 2 a 3 anos, após o que o pasto deveria estar definitivamente plantado.

Outra seqüência também observada era o desmatamen to para o plantio dos cafezais, permitindo-se o uso das entre-ruas com cultivo de cereais. 0 pasto, nessas con dições, viria substituir o café quando a "cultura cansada" não apresentasse lucros compensadores.

A grande mudança de qualidade no plantio dos pastos de capins se daría com a intensificação de um comércio direto de sementes entre propriedades agropecuārias. As vastas invernadas plantadas por mudas, numa etapa anterior, asseguravam o fornecimento de sementes para a expansão das áreas da própria empresa e ainda excedentes para a comercialização. As primeiras distin ções entre sementes "do cacho" ou "de varredura" (colhidas no chão) chamavam a atenção do usuário sobre as diferenças de germinação do material obtido nessas duas condições.

As sementes colhidas na inflorescência ("cacho") apresentam vários estádios de maturação dos cariopses e a porcentagem de germinação iria depender de um julgamento subjetivo para a melhor época de colheita. As recolhidas do chão, consideradas de melhor qualidade, cor respondem aos cariopses maduros que caem naturalmente ao solo. A inconveniência neste caso é que de mistura com a varredura, sementes das plantas indesejäveis eram levadas à outras regiões, muitas vezes prejudicando a composição botânica pretendida.

Os capins que predominaram com quase absoluta exclusividade até as décadas de 30 e 40 pertencem às 
seguintes espécies: gordura - Melinis minutiflora; colonião, guiné - Panicum maximum; jaraguá Hyparrhenia rufa; angola, fino - Brachiaria mutica. 0 quicuiu, in troduzido em 1923 (46), ficaria restrito às regiões subtropicais temperadas.

Värios autores $(56,31,41,46,47)$ confirmam a origem africana desses capins, trazidos provavelmente nas camas dos escravos em navios provenientes do Continente Africano.

o capim Guiné (Panicum maximum) teria penetrado no Continente Latino-Americano em $1741 \mathrm{e}$, no Brasil, na altura da Bahia, no século XVIII, em data não bem deter minada. Essas introduçōes se deram, por via marítimá, em função do comércio de mercadorias e tráfico de escravos entre o Continente Africano e as costas atlânticas da América Central e do Sul $(46,47)$. Há contudo fortes evidências da presença do "Guiné" na América Central, de certo a espécie de pasto coletada por Hans Sloane em 1684 em Barbados e classificada como"Paniceum vulgare" ou Gramen paniceum maximum (47). Outra fonte (72) refere-se à presença dessa Panicum, com a mesma designação comum de "Guiné" e do "Angola", com apoio na descriçao do historiador Frei Vicente (Salvador, BA) aproximadamente em 1549, época em que já se assinalava a presença do escravo africano para trabalhar nos engenhos de cana-de-açúcar.

A designação "Guinē" para a graminea da espécie Panicum maximum denota, certamente, apenas sua origem africana. Os tipos encontrados na prática, desde longa data, como o Colonião, Guiné, Guinezinho, Sempre-Verde, Touceira do Ceará, Coloninho do Paraná, etc. podem ter sido introduzidos ao longo dos séculos em que prevaleceu o tráfico de escravos. E também possível que a espécie, a despeito de ser apomítica (não obrigatória), tenha desenvolvido essa série de tipos nos múltiplos e variados ecossistemas em que foi progressivamente penetrando nesses aproximados 400 anos.

0 capim Angola ē também citado por Frei Vicente (72) 
em 1549 è considerado, juntamente com o "Guiné", como de introdução mais antiga nas Américas (47). A reconstituição documentada de sua vinda para o Brasil data do sëculo XVIII, com referências mais específicas em 1872 na América Central e em 1823 no Estado do Rio de Janeiro, também proveniente do país de Angola, na África (72).

Essa espécie tem alguns nomes comuns-Angola, Fino, Bengo, Pará - Brachiaria mutica (Panioum purpurascens Raddi). Distribui-se do Rio Grande do Sul ao Amazonas, ocupando de preferência as baixadas úmidas mas alcança posições de regimes hídricos mais limitados. Pelo menos três tipos são encontrados na prática: Angolão, Angola (ou Fino) e Angolinha, de fäcil distinção (43). Não são conhecidos estudos, em nosso meio, visando a identificaçāo de ecótipos de $B$. mutica para as diferentes situaçôes ecológicas.

o capim Jaraguá (Hyparronenia rufa) originārio da Costa Angolana na Áfica, teria atingido o Brasil na al tura do Litoral Baiano no século XVIII. Dotado de notável agressividade e grande capacidade de penetração de suas sementes no solo, o "Jaraguá" compete vantajosamente com os capins naturais do cerrado.

A variabilidade genética da $H$. rufa é muito limitada, pelo menos fenotipicamente, segundo observações do autor deste trabalho. Não é fácil, contudo, explicar seu ótimo comportamento em nichos ecológicos bastante distintos, nas regiões do Brasil Central, Norte e Nordeste.

A escassa documentação disponível permite apenas concluir que a $H$. rufa foi introduzida nas Américas em data posterior à atribuída ao "Colonião" e "Angola".

0 quarto capim que constitui mais um pilar no embasamento da pecuäria tropical/subtropical no Brasil, de introdução anterior ou durante o século XVIII, é o Gordura (Melinis minutiflora). A primeira descrição científica da espécie deu-se em 1812 de especimem 
coletado próximo à cidade do Rio de Janeiro (47). Em 1816 (47) ou 1817 (41) Saint Hilaire observou sua presença em Minas Gerais $\left(17^{\circ} 40^{\prime} \mathrm{S}\right)$ e Gardner em 1846 assinala a ocorrência da espécie bem mais ao norte. No mesmo sentido, Martius julgava que a espécie era nativa do Brasil (46).

A data e o modo de introdução do "Gordura" no Novo Mundo são desconhecidos mas, dada sua capacidade de adaptação aos solos pobres, espalhou-se rapidamente pelos climas tropicais e subtropicais do país, colonizando ainda terras desgastadas com a cultura do café, de maneira subespontânea. E uma espécie que prevalece ainda em muitas áreas montanhosas no Brasil Central, atualmente.

Melinis minutiflora é uma gramínea apomítica que, no entanto, apresenta värios tipos comerciais bem distintos como "Gordura", "Francano", "Cabelo de Negro", etc., além de apreciável variabilidade fenotípica como tem sido observado por alguns pesquisadores.

A hipötese de que as camas dos navios traficantes de escravos da Africa para as Américas, feitas de capins, estariam introduzindo na descarga de destino, espécies vegetais, é também aceita pela renomada agrostologista Agnes Chase (46). Essa via de transporte de capins africanos para o Novo Mundo, aceita por conceituados pesquisadores, permite com razoāvel possibilidade, atribuir datas bem anteriores para a presença do P. maximu, $H$. rufa, B. mutica e $M$. minutiflora no território brasileiro. Por volta de 1575 jā havia no Brasil, em função da indústria açucareira, cerca de 10.000 africanos (3). No mesmo sentido outra fonte (18) informa que "o trä́fico de escravos negros trazidos da África para o Brasil começou em meados do século XVI, ampliando o comércio dessa máo-de-obra, que jā era praticado pelos próprios portugueses a partir das ilhas Canárias e São Tomé, e pelos espanhois, para a região do Caribe e São Domingos, na América, além dos ingleses". Quantos desembarques teriam ocorrido para a 
vinda de 10.000 pessoas africanas, como registrado por pesquisa recente ( 3 ), aumentando a chance de penetração de novas espécies em território nacional! o transporte consciente de sementes ou de propágulos de plantas pela população negra deve também ser considerado pois há precedentes com referência específica ao capim Quicuiu (Pennisetum clandestinum) que teve sua expansão incrementada no território africano pelo häbito de "os membros de cada familia, quando deixavam suas casas, levavam consigo um feixe de rizomas para formar novos pastos", como relata Walt em 1925 (6).

A presença do grupo $P$. maximum en terras de floresta permitiu um aumento de produtividade em todas as fases do criatório bovino, particularmente na terminação do novilho para o abate, com ganhos médios de peso vivo ao redor de $0,5 \mathrm{~kg}$ diārio por cabeça. No Nordeste, em clima sub-úmido, uma espécie de $P$. maximum, o "touceira do Ceara" representa ainda hoje um recurso forrageiro de boa expressão econômica. Os ecótipos naturais do $M$. minutiflora penetraram nas áreas de cerrado à medida que se reduzia, pela pressão animal, a densidade da sombra, ajudando a expansão do estrato herbáceo. Nos solos de cerradão, geralmente favorecidos pela inclusão de basalto, as condiçoes edáficas permitiram a invasão de $H$. rufa que, além da cria e recria, possibilitou ainda a engorda de animais com carcaças mais pesadas que as provenientes do Colonião (45). 0 "Angola" ou "Bengo" ( $B$. mutica) encontrou seu habitat preferido nas terras frescas e de difícil drenagem; for nece boa produção relativa de forragem no outono alem de iniciar a brotação de primavera com certa vantagem sobre os outros capins. Basta lembrar em favor dessa afirmação ter sido o "Angola" a espécie preferida pelos vaqueiros junto aos grandes centros para formar seus pastos e capineiras, com disponibilidade de verde quase 0 ano todo.

"O gênero Cynodon comporta espécies ubíqüas que participaram do processo de africanização das pastagens de gramíneas da América Tropical" (7). C. dactizon é 
encontrada em todo o território brasileiro mormente em areas ruderais, chegando a ser considerada invasora em terras de cultura.

As quatro espécies consideradas atenderam ao cres cimento da pecuäria tropical/subtropical brasileira des de seu início, ocupando uma multiplicidade muito grande de ecossistemas naturais e induzidos, em vários milhões de hectares, do norte ao sul do país. No decorrer desses séculos, as espécies tornaram-se perfeitamente naturalizadas no Brasil e em värios países da América Central e do Sul.

Na região Sul do país as primeiras introduções de novas espëcies forrageiras foram de Azevém (Lolizm muZtiflorum) e trevos (Trifolium spp) principalmente, seguidas de outras originárias de clima temperado/subtropical.

\section{A EVOLUÇAOO DA PESQUISA}

0 progresso verificado na pecuária brasileira des de os idos de 1540-1550 (72) com, provavelmente, 2 a $\overline{3}$ centenas de bovinos até 1980 quando somavam 122.632 .425 cabeças (26), não pode ser observado apenas numericamen te. A produtividade animal, a definição de áreas de pastejo naturais e plantadas, a estacionalidade forrageira, etc. precisam ser considerados em conjunto para o estabelecimento de um quadro mais realista.

A pecuária extrativa, ainda muito expressiva atualmente, utiliza-se dos recursos naturais com um minimo de interferência humana. Assim é que a pressão animal (boca e casco), as queimadas e o uso das cercas têm se constituído nos principais elementos para o desbravamento e controle de imensas áreas cobertas por di ferentes formações vegetais.

A interação dessas forças boi/fogo/cerca permitiu razoável domínio da vegetação para que empresas pecuárias se instalassem progressivamente com apreciável 
estabilidade. Esse processo secular perdura ainda hoje como primeiro recurso para se penetrar, p.ex., na Amazônia e no cerrado (1.s.). Alguns recursos resultantes da pesquisa se associam às vezes ao primitivismo da pecuária extensiva. E o caso da semeadura aérea de capim em grandes áreas de floresta após o corte e queima da vegetação. Pode-se citar também o emprego de herbicidas para eliminar a "juquira", vegetação indesejável que compete com o capim semeado. A mineralização do re banho com misturas feitas à base de levantamento de carências regionais é bem aceita pelos pecuaristas e permitiu o florescimento de indústrias especializadas no ramo.

Embora os problemas principais da pecuária possam ser aliviados momentaneamente com alguns recursos da tecnologia, não se sabe o que ocorrerá a longo prazo nesses ecossistemas. O convívio com extratividade na pecuäria bovina depende, obviamente, do tipo de solo e de sua riqueza mineral e orgânica. Estes fatores e a carga animal constituem as principais determinantes da velocidade de degradação do meio, quando as técnicas disponiveis não são utilizadas.

Veja-se o exemplo da Noroeste Paulista em que o "Colonião" engordava 4 a 6 cabeças por alqueire nas novas invernadas, reduzindo-se depois de alguns anos a menos da metade, além de expor o terreno à penetração de invasoras como o "leiteiro", o "assa-peixe", à grama forquilha (de qualidade inferior), etc.

Nas regiões de terra fraca o problema é semelhante mas muito mais intenso, como nos "campos", cerrados e cerradões. As espécies semeadas dispõem de um acümulo muito menor de matéria orgânica e minerais e, portanto, sua velocidade de degradação é mais acelerada. 


\section{CICLO DOS CAPINS}

As primeiras formulaçōes feitas pelos pecuaristas para enfrentar o problema das pastagens degradadas resumiam-se na busca de espécies forrageiras que se costumou chamar de "planta milagrosa" ou "capim milagroso". Esse capim deveria "ir bem na terra fraca e fornecer algum verde na seca". Aparentemente destituído de bom senso, esse enfoque passou para o forum das Universidades e Centros de Pesquisas, resultando nos conhecidos "ciclos dos capins", através de coleta em territörio nacional e introduçôes do exterior, ampliando a disponibilidade de plantas de pasto para fins de estudos.

Tratava-se em realidade de reajustar os ecossistemas pastoris embasados no $P$. maximum, $M$. minutiflora e $H$. rufa, já desgastados pelas queimas e lotações excessivas. As pastagens de $B$. mutica, situadas em nichos mais preservados e reabastecidos em nutrientes minerais pela sua localização em baixadas, se mantêm até hoje com menores problemas.

Os Centros de Pesquisas desde longa data jà vinham se preocupando em conhecer a flora das espécies forrageiras brasileiras, nativa ou naturalizada. Campos de agrostologia foram disseminados pelos Institutos de Pesquisa e Escolas de Agronomia do país desde a primeira década deste século, ampliados e enriquecidos com novas espécies nativas e exóticas a partir de então. E interessante ressaltar que em 1922 já se publicava um Diccionārio Abreviado de Plantas Forrageiras (12) relacionando e descrevendo 186 espécies, das quais 101 capins, 57 leguminosas, 1 ciperácea, 1 cactácea e 26 outras. A criação das 12 Escolas de Agronomia e 3 Institutos até os anos 20 (42) permitiu a focalização das questöes de pastos e animais pelos estudiosos, na época, com valiosa troca de informações.

Sob influência de especialistas estrangeiros contratados nas primeiras décadas deste século, inicialmente 
na Europa, para colaborarem nos programas de produção animal, o estudo das plantas forrageiras se concentrava na sua identificação botânica e análise bromatológica, com algumas recomendações, ainda gerais, sobre adubação.

Dos levantamentos botânicos e coletas de espécies nativas, pouco resultou de positivo para o enriquecimento da flora agrostológica útil. A não ser algumas espécies de uso restrito de Paspalum como o dilatatum, notatum e plicatulum, Grama Missioneira (Axonopus compressus), Canaranas (Echinochloa piramidalis, principalmente) e Sorgo Negro (Sorghum almum), não foram selecionados outros capins, de uso generalizado.

o grande manancial de gramíneas forrageiras tropicais/subtropicais se localiza na Africa e foi desse continente que se originou a totalidade das espécies que povoam nossas pastagens plantadas nas regiões tropicais/subtropicais.

Muito antes de terem se iniciado os "ciclos dos capins", ocorreu em 1923 (46) a introdução do "Quicuiu" (Pennisetum clandestinum), gramínea de características invasoras nos climas amenos. Segundo nossas observações pessoais, essa forrageira naturalizou-se nas regiões montanhosas e sul do Estado de São Paulo. Na mes ma época $(43,5)$ outra espécie de notáveis características forrageiras, o capim Elefante ( $P$. purpureum) exigente de fertilidade e de difícil controle sob pastejo, ficou restrito às capineiras de corte. Para o capim de Rhodes (Chloris gayana) não se dispõe de data referente à sua entrada no Brasil, mas figura jä em 1922 no Diccionário Abreviado de Plantas Forrageiras (12). Assim como o "Quicuiu", as gramas da espécie C.dactyzon, - "Rhodes" tem sua utilização quase que limitada aos pastos para equĩdeos.

Dentre outras ocorrências antigas de gramineas que tiveram pequena expressão como forrageira pode-se citar o "Favorito" (Rhynchelytrum roseum) e o capim do Sudão - Sorghum sudanense (Andropogon sorghum). 
Introduções anteriores à década de 20 se fizeram em larga escala para a Região Sul do Brasil, casual ou conscientemente, dentre as quais cabe destacar: alfafa (Medicago sativa), alfafa de flor amarela (M. Lupulina), trevo de carretilha (M. hispida), trevos (Trifolium repens, T. incarnatum, T. pratense), "Azevém" (Lolium milfilomm) em 1875 (5), "Falaris" (Phalaris tuberosa, $P$. minor), etc.

0 "ciclo dos capins" propriamente dito constitui uma atitude mais avançada, e talvez a unica possivel do ponto de vista económico, visando alterar quantitativa e qualitativamente a disponibilidade de pasto para um rebanho em franca evolução. Esse posicionamento é passivel de críticas quando busca equacionar o problema de baixa produtividade dos pastos por intermédio de um "super-capim" esquecendo-se dos demais componentes do meio. A nível de pesquisa, contudo, o material botânico passou a ser avaliado quanto às suas qualidades agronômicas, forrageiras, etc. Ampliaram-se assim as oportunidades para que as novas espécies, além dos quatro capins "clássicos", fossem estudadas junto aos institutos e universidades no que respeita as suas respostas à adubação, sistemas de corte, aceitação pelos animais, tolerância a pragas, moléstias, frio, seca, pastejo, comportamento em diferentes solos e climas, etc.

\section{CAPIM PANGOLA}

0 capim Pangola (Digitaria decumbens) introduzido em 26/05/48 dos E.U.A. pelo Instituto Agronômico de Cam pinas, ficou restrito à estudos de conservação do solō (54). Novas introduções se deram em 1950 e 1960 por técnicos do antigo Depto de Produção Animal, com material proveniente, respectivamente, da Flörida e Venezuela (54). Atribui-se a estas duas origens a totalidade dos pastos cultivados no Estado de São Paulo até 1962. 
Quase certamente o "Pangola" inicia os värios ciclos de entrada com novas gramíneas no país. Esse capim apareceu no cenário agrostológico brasileiro justamente quando as melhores invernadas de colonião e jaraguá encontravam-se em franca decadência. Substituiu as espécies tradicionais, com grande aceitação pelos pecuaristas, a despeito do seu plantio oneroso por via vegetativa. De häbitos rasteiros, crescendo através dos estolões, o Pangola rapidamente integrava a ocupação do terreno.

Por se tratar de planta que não produz sementes, surgiram, na prätica, problemas para seu estabelecimento em grandes áreas. Os Centros de Pesquisas e Universidades multiplicaram os estudos sobre sua propagação, desde a manual até a mecanizada, tendo surgido máquinas especiais fabricadas pela indústria para facilitar seu plantio.

0 uso do Pangola não se limitou aos pastos para bovinos, ovinos e caprinos, tendo sido utilizado nos Haras, em piquetes para eqüinos. A fenação, facilitada pela estrutura delicada de suas folhas e colmos, teve apreciável incremento, ajudando a armazenar os excessos de produção que sempre ocorrem no período de outubro a março no clima Aw.

Ensaios de respostas a doses crescentes de nitrogênio, de digestibilidade, de resistência e rendimento sob pastejo, entre outros, ocuparam os estudiosos dessa graminea de norte a sul do país. 0 "Pangola" penetrou nos mais diferentes habitats, desde o Rio Grande do Sul ao Nordeste Brasileiro.

Ao lado desse sucesso que durou alguns anos, foram surgindo problemas, especialmente os de sanidade. Por se tratar de uma espécie estéril, a $D$. decumbens apresenta dificuldades para seu melhoramento genético. Sensivel ao virus causador do "little leaf", sofreu ain da a ação da cigarrinha (Deois spp) e principalmente da cochonilha (Antonina graminis). 
A importação da India de uma vespa (Neodusmetia sangwani), posteriormente criada em laboratório junto a órgãos oficiais, no Brasil, permitiu o controle biológico da $A$. graminis. Com esse emprego de tecnologia beneficiaram-se também o "Angola" (B. mutica) e outros capins parasitados pelo inseto, em nosso meio (40).

o gênero Digitaria com a "febre do Pangola" motivou os pesquisadores na obtenção de outras variedades e espécies. Das novas importações que se sucederam, a que mais se destacou foi a cv. Transvala ( $D$. decumbens) de boa aceitação atual e superior ao "Pangola" em resistência a doenças e produção (7). A espécie D.swazilandensis adquire, progressivamente, popularidade junto aos pecuaristas no Estado do Rio de Janeiro, onde $\vec{e}$ conhecida pelo nome de "Suazi".

\section{GENERO CYNODON}

Valiosa contribuição foi recebida da Coastal Plain Experimental Station, Georgia, E.U.A., com o lançamento de vārias cultivares de Cynodon como "Coastal Bermuda", "Suwannee Bermuda" e outras para campos de esporte. O grande destaque para o gênero foi a disponibilidade em 1967 da "Coast Cross no 1" (13), resultado do cruzamento da cultivar Coastal com $C$. nlemfuensis var. robustus, concorrendo efetivamente para consagrar o grupo Cynodon, face a seu elevado valor nutritivo.

Algumas espécies de Cynodon como plechtostachyus (capim estrela) e nlemfuensis (capim estrela de Porto Rico) têm tido aceitação regional. A cv. estrela de Porto Rico, p.ex., popularizou-se entre criadores do Estado do Rio de Janeiro, principalmente para produção de leite a pasto e figura entre os principais capins distribuídos atualmente pela PESAGRO-RIO. 


\section{PENNISETUM PURPUREUM}

Dentre a série de novas introduçoes são encontradas muitas vezes, variedades ou ecótipos de espécies conhecidas como as do grupo $P$. purpureum que comporta enorme variabilidade. Pelo menos 25 "provāveis variedades" foram estudadas competitivamente em um único ensaio, para produção de matéria seca, composição bromatológica e digestibilidade (2). Novas cultivares são continuamente anunciadas, seja de material importado ou de variação originária de sua "fecundação cruzada obrigatória, ao que tudo indica" (2) das plantas existentes desde värias décadas em solo brasileiro. Em 1961 são relatadas apenas 2 variedades de $P$. purpureum (43), as tradicionais cvs. Napier e Mercker, enquanto na década de 80 calcula-se ser superior a trinta, sob experimentação em diversos centros.

A focalização de se dispor de reserva forrageira para o período seco em bases económicas, encontrou no capim Elefante matéria-prima de boas características pa ra ensilagem e de grande aceitação junto às empresas pecuärias. Paralelamente têm sido desenvolvidas continuamente inúmeras técnicas de emprego de aditivos para melhorar a conservação e qualidade da silagem com esse capim.

O P. purpureum permitiu ainda a elaboração de vários experimentos em pastos adubados, visando à produção económica de leite e ganho de peso vivo, com o emprego de nitrogênio industrial ou leguminosas $(38,37$, $36,48)$.

\section{CAPIM GUATEMALA}

Tripsacum laxum foi mais popularizado nos anos 60 e a melhor distribuição de forragem no outono / inverno assegurou por longo tempo sua utilização como planta de corte. Como o "Elefante" serve para ser ensilado, mas não suporta a ação do pisoteio. 


\section{PANICUM MAXIMUM}

o grupo P. maximum permitiu também, por aquisição de vărias cultivares, o início de um "ciclo dos Panicuns importados", disponiveis comercialmente na Austrālia. As cultivares "Green panic", "Gatton panic", "Hamil", "Sabi panic", "Embü", "Makueni", "Riverdale", figuraram, nos anos 60 e 70 , em ensaios competitivos com os Colonião, Sempre Verde, Guiné, Guinezinho, "Coloninho", "Coloninho do Paranā", "Colonião de Tanganica", "Pãnico-Worth", "Bufalo", etc. Essas introduções se fizeram principalmente na década de 70 e, aparentemente, apenas o "Green panic" se incorporou em alguns ecossistemas das áreas de cerrado.

A partir de 1983, mediante convênio firmado entre a ORSTOM e EMBRAPA/CNPGC em 1981, foram recebidos 426 acessos apomíticos de $P$. maximum além de 417 plantas sexuais (35). Sobre coleções amplas podem ser planejados trabalhos de seleção e genética.

\section{SETARIA SPHACELATA}

Ainda nos anos 70 a entrada no país da Setaria sphacelata, com três cultivares - "Nandi", "Narok" e "Kazungula" permitiu a formação de pastos em regiões sujeitas a frios intensos. De introdução anterior a 1960 havia a cv. Marangá, rebatizada na prática com o nome de "Rabo de Cachorro" e que se comportava satisfatoriamente no sul do Estado de São Paulo (29). A cv. mais utilizada tem sido a "Kazungula" de bom comportamento produtivo nos climas amenos, com ocorrência de geadas leves, e ainda em algumas áreas do Pantanal do Mato Grosso.

\section{O GÊNERO BRACHIARIA}

A partir do início dos anos 60 surgiu um dos ciclos de capins mais duradouros e de franca expansão 
nestes 25 anos. O gênero Brachiaria, inicialmente representado pela $B$. decumbens proveniente do Parä, com a cv. IPEAN e alguns anos mais tarde com a cv. Australiana, causou verdadeira "revolução agrostológica".

A espécie que no começo era destinada aos solos pobres das áreas de cerrado, passou a ser usada indistintamente nos mais variados tipos de terra. 0 plantio por via vegetativa se deu apenas nos primeiros anos, pois as sementes de bom valor cultural permitiram sua rápida ampliação de norte a sul. o êxito obtido com a $B$. decumbens propiciou, obviamente, a busca de novas es pécies e (ou) ecótipos em solo africano, tendo sido introduzidas: $B$. miziziensis, $B$. humidicola, $B$. brizantha e $B$. arrecta. A $B$. humidicola denominada de "Quicuiu do Amazonas", adaptou-se bem às condiçoes ecológicas ali reinantes e ampliou-se em apreciāvel extensão. A "Tanner grass" de otimas qualidades agronômicas, teve sua posterior propagação proibida por ter sido constatada sua toxidês para bovinos em muitas ocasiões, além de ser hospedeira do inseto Blissus leucopterus como verificado por diferentes autores (7). A B. arrecta e B. mutica apresentam um híbrido natural "Tangola", surgido no norte do Estado do Rio de Janeiro (63) que atualmente ocupa āreas consideráveis da Baixada Litoránea desse estado, além de ser usado em outras regiões do país. Aparentemente a toxicidade do "Tanner grass" foi atenuada com o cruzamento com o Angola, mas hă casos de pecuaristas que se queixam dessa limitação no Tangola, o que tem sido objeto de atenção de alguns centros de pesquisa.

Com pretensões mais abrangentes para se avaliar a variabilidade do gênero Brachiaria, foi estabelecido um amplo programa junto ao CNPGC, Campo Grande, MS. Pelo menos 840 acessos, obtidos de 25 espécies, estão sendo estudadas por cerca de 35 descritores morfológicos, além de aspectos relacionados com o modo de reprodução, indispensáveis aos trabalhos de melhoramento genético (71). Todo esse material resulta de coleta realizada em vários países da Africa por iniciativa do CIAT (Centro 
Internacional de Agricultura Tropical) e IBPGR (International Board for Plant Genetic Resources) em $1984 / 85$.

A agressividade e facilidade de adaptação das bra quiärias em solos pobres a férteis tem, de certa forma, prejudicado a presença de espécies mais produtivas e de melhor aceitação pelo gado. Vê-se com grande freqüencia, p.ex., braquiária em terra que comporta o capim Colonião, em prejuízo da produtividade animal.

No Estado de São Paulo, segundo levantamento do Inst. de Economia Agrícola de 1987, cerca de 4.053 .853 hectares de terra acham-se cobertos com quatro espécies de Brachiaria (decumbens, humidicola, brizantha, ruziziensis) ou 54\% das āreas de pastos plantada (14). Trata-se de uma solução aparente e a médio prazo, de um problema forrageiro que certamente irä criar novas dificuldades para o futuro.

\section{CAPIM BUFFEL}

Dentre as vārias introduções feitas nas regiões sub-ümidas do Brasil, no Nordeste, o grupo Cenchmis ciliaris é o que melhor tem se adaptado às condições hídricas (distribuição irregular principalmente) da região. Nada menos que 20 cultivares são citadas, sendo 11 de porte alto, 7 de porte médio e 2 de porte baixo. Sua origem, na Âfrica, estende-se ainda à India e Indonésia. Além dessa disponibilidade o Banco Ativo de Germoplasma do Centro de Pesquisa Agropecuária do Trópico Semi-Arido conta com cerca de mais 100 acessos de C. ciliaris, visandc ampliar a variabilidade genética e atender aos vārios sub-ecossistemas do nordeste, com carência e irregularidade nas precipitações pluviométricas (62).

Algumas cultivares $j \bar{a}$ foram testadas a nivel de campo para produção de matéria seca e ganho de peso vivo, sob pastejo, com resultados iniciais animadores. 


\section{ANDRCPOGON GAYANUS var. BISQUAMULATUS}

A despeito do grande sucesso obtido com as braquiārias, o pecuarista está sempre interessado em experimentar o novo capim em suas terras. Inicia-se assim mais um ciclo, o do andropógom, competindo com o já con solidado grupo das braquiárias e bem aceito entre os criadores.

No início da atual década procedeu-se à introdução do A. gayanus var. bisquamulatus cv. Planaltina, destinado aos solos de baixa e média fertilidade. Sua adaptação produtiva em värios ecossistemas de terras fracas tem despertado maior desenvolvimento da pesquisa no sentido de conhecer suas características sob värios aspectos forrageiros. Seu porte ereto, contrariamente às braquíarias, permite mais facilmente a associação com leguminosas. Possui ainda a vantagem de ser de espécie alógama, passível de melhoramento genético mais rápido que na maioria dos capins tropicais com pro dução apomítica de sementes.

Uma introdução anterior há cerca de 30 anos, de A. gayanus var. squamizatus conhecida como "Gamba", apresentava problemas de produção de sementes, limitando o interesse por sua utilização (7).

\section{LEGUMINOSAS}

A grande disponibilidade de gramineas propiciada pelas introduções seculares do "Gordura", "Jaraguä", "Guiné" e "Angola" além das provenientes dos denominados "ciclos de capins", incluindo algumas iniciativas isoladas de órgãos de pesquisas ou mesmo pecuaristas, não daria solução a longo prazo para uma pecuäria, em sua grande maioria, extrativa.

0 problema central de manutenção ou aumento da fertilidade do ecossistema das pastagens depende essencialmente de corrigir as carências minerais dos solos, de maneira preventiva logo no ano do plantio ou quando 
do surgimento dos primeiros sintomas de degradação. Além da adubação básica $P, K, S$, antecipada ou não de calagem ( $\mathrm{Ca}, \mathrm{Mg}$ ) para eventual correção de $\mathrm{pH}$, o nutriente ou a "gasolina que movimenta o pasto" segundo J.C.Werner, é o nitrogênio. Este elemento é bastante oneroso e de grande instabilidade no sistema do pasto; precisa ser continuamente reabastecido para atender ao crescimento das plantas forrageiras além de sua renovação após pastejo.

Pela via biológica de fornecimento de $\mathrm{N}$ ao pasto através da sua fixação simbiótica leguminosa/Rhizobium, esse nutriente, retirado do ar, entra a custo zero, além de elevar o teor protéico da forragem devido à grande concentração de nitrogênio no macrossimbionte.

Esse fato era conhecido pelos pesquisadores pioneiros no estudo das pastagens, como Souza Brito que em seu Diccionārio Abreviado de Plantas Forrageiras publicado em 1922, incluiu 30\% de leguminosas, a grande maioria nativa no Brasil. Acrescente-se ainda o notável trabalho realizado por J.R.Otero em 1939, levando a efeito a primeira coleta de capins e leguminosas naturais de áreas de pastejo no Estado de Mato Grosso, on de ficou evidenciada a presença de inümeras leguminosas forrageiras: Desmodium, Centrosema, Styzosanthes, Arachis, Zomia, Tephrosia, Indigofera, Clitoria, Eriosema, Cassia, Aeschynomene (44). Novas coletas organizadas se fariam nos anos 1961-1963 pelo Instituto de Pesquisas IRI sediado na cidade de Matão, SP (69). Destas introduções resultou o lançamento, pelo Instituto de Zootecnia, da cv. NO-548 da espécie Galactia striata após uma série de estudos feitos em parcelas e com a presença do animal (28).

Novo projeto apoiado financeiramente pelo BNDS, a fundo perdido, foi realizado de 1976 a 1979 pelo Instituto de Zootecnia, Nova Odessa, SP, com a introdução de sementes de 1074 coletas de leguminosas, conservadas em bancos de gens, para estudos posteriores. Dessa coleta jâ resultou o lançamento de mais uma leguminosa, a 
Galactia striata cv. Yarana/IZ. $3(33,55)$.

Em 1973 inicia-se na EPAMIG - Empresa Agropecuāria de Minas Gerais, um amplo programa estadual de coleta de leguminosas, na qual o genero Stylosanthes foi enriquecido com a constatação de 10 novas espécies. No total foram introduzidos 109 espécies inclusas nos gêneros: Aeschynomene, Arachis, Calliandra, Calopogonium, Camptosema, Canavalia, Centrosema, Chaetocalyx, Clitoria, Collea, Cratylia, Crotalaria, Desmodium, Eriosema, Galactia, Periandra, Phaseolus, Rhynchosia, Stylosanthes, Teramus, Vicia e Zornia (20).

No NE Brasileiro cuidou-se através do Convênio SUDENE/DNOCS (1980) da identificação e inventário de forrageiras nativas, destacando-se espécies dos gêneros: Aeschynomene, Arachis, Cassia, Canavalia, Centrosema, Calliandra, Desmodium, Dioclea, Desmanthus, Galactia, Stylosanthes, Tephrosia, Indigofera, Phaseolus, Rhynchosia, Zormia(*).

Amplos levantamentos da flora dos campos naturais do Rio Grande do Sul foram feitos para conhecimento e identificação de capins e leguminosas. Desta família foram constatadas 82 espécies de leguminosas em 31 gêneros, com destaque para Adesmia, Desmodium, Phaseolus, Vicia.

Um grande impulso na disponibilidade de leguminosas forrageiras foi dado com a criação do Centro Nacional de Recursos Genéticos - EMBRAPA, em 1974. De amplitude nacional e continental o programa de coleta tem alcançado resultados extraordinários em suas introduções, seguidas de quarentena, conservação ao longo prazo e documentação por sistemas computadorizados (52). Dentro do gênero Stylosanthes jā foram lançadas duas cvs.,Bandeirante e Pioneiro $(65,66)$, destinadas aos solos dos cerrados.

(*) SAMPAIO, G.R. (DIRGA/CE, Fortaleza). Correspondência pessoal, 1982 . 


\section{BACTERIOLOGIA}

A bacteriologia de Rhizobium experimentou, nos anos 60, grande desenvolvimento à medida que novas coleções de leguminosas eram estudadas isoladamente ou associadas aos capins. Nas excursões de campo dotadas de maiores recursos, procedia-se também à coleta de nódulos de rizóbios nas raízes das leguminosas. Nos 1 aboratórios dos institutos de pesquisas dos Estados do Rio de Janeiro, Rio Grande do Sul, São Paulo, Paraná e outros, desenvolveram-se técnicas as mais diversas de isolamento e armazenamento de culturas puras, métodos de inoculação, reação aos diferentes índices de $\mathrm{pH}$ do meio, etc. Sistemas especiais de peletização das sementes com inóculo para plantio foram desenvolvidos e tiveram seu sucesso demonstrado a nível de campo.

Muitas definições foram feitas pelos pesquisadores quanto à necessidade de se empregar ou não inoculan tes em determinados solos e climas na faixa tropical $/$ subtropical. No mesmo sentido conhecem-se as leguminosas que se beneficiam com o inóculo específico e outras que não necessitam dessa prätica $(21,15)$.

\section{PASTAGENS DE CAPINS}

Pelo fato dos capins serem plantas consumidoras de nitrogênio, os sistemas tradicionais montados com representante(s) exclusivo da família Gramineae dependem de uma fonte que supra esse nutriente. Os fertilizantes nitrogenados atendem a esse objetivo mas não têm sido aceitos na grande maioria das empresas pecuärias por serem anti-económicos.

A experimentação que se instalou em torno desse conceito de produção de matéria seca de forrageiras tem sido das mais abrangentes. Praticamente todos os capins introduzidos foram e continuam sendo submetidos a sistemas de corte, combinando frequência, altura e níveis de adubação. Os adubos, de simples misturas $P K$, 
com ou sem calagem, passaram, de acordo com caréncias regionais conhecidas, a ser suplementados com micronutrientes. A aplicação de nitrogênio, principal promotor da produção de m.s. já se fazia em diferentes níveis combinados com épocas distintas, na tentativa de distribuir a disponibilidade de forragem ao longo do ano, o mais uniformemente possivel.

Por esse processo conhecem-se inúmeras curvas de respostas dos capins à aplicação de fertilizantes, em diferentes niveis e sistemas de corte. 0 transporte dessa tecnologia para os pastos envolve värios fatores mas, um deles, o do custo do adubo, costuma ser a principal barreira para sua efetivação a nível de empresa.

Em alguns poucos casos, como na produção de leite a pasto, durante a estação de crescimento do capim, os retornos econômicos são considerados econômicos $\mathrm{fa}^{-}$ ce às elevadas produções por animal (de acordo com seu potencial genético) e por área (em função da espécie de capim e dos níveis de adubação) $(38,37,9,8,17$, $61,73)$.

Os tratamentos mais promissores combinando "ca$\mathrm{pim} / \mathrm{sistema}$ de corte/níveis e épocas de adubação", eram levados ao campo, sob pastejo, para estudo de sua economicidade. Grandes diferenças de ganho de peso vivo entre os vigentes na prätica e com emprego de tecnologia evidenciam o potencial existente para a produção de carne: de 13,35 a $15,27 \mathrm{~kg} \cdot \mathrm{ha}^{-1} \cdot$ ano $^{-1}$ no "campo $1 \mathrm{im}$ po" e 61,12 a $78,37 \mathrm{~kg} \cdot \mathrm{ha}^{-1} \cdot$ ano $^{-1}$ no "pasto natural do cerrado" (74), para $456,4 \mathrm{~kg} \cdot \mathrm{ha}^{-1}$. ano-1 em pastos com adubação básica mais nitrogênio (53).

\section{PASTAGENS MISTAS}

A formulação, ainda incipiente, dos estudiosos brasileiros de pastagens no final da década de 50, em considerar a leguminosa no pasto não apenas uma planta rica em proteína mas como verdadeira "fäbrica de nitrogênio", foi fortemente influenciada por alguns eventos 
de repercussão universal. Em 1965 realiza-se no Brasil o IX Congresso Internacional de Pastagens, o primeiro nos trópicos, e, neste forum, as teses dos pesquisadores nacionais, enriquecida com as contribuições cientificas de outros paises, foram amplamente debatidas. Ressurge o interesse por essa curiosa associação leguminosa/Rhizobium que consegue retirar do ar o nitrogênio indispensável à manutenção dos níveis de produtividade do ecossistema do pasto.

Experimentos com leguminosas tropicais/subtropicais se instalaram em diferentes regioes brasileiras, iniciando, como no caso dos capins, por cortes/alturas/ frequēncias/adubações-épocas mas com a diferença fundamental de não se utilizar de nitrogênio. Nesse contexto a nutrição do rizóbio teve que ser reexaminada em condições brasileiras, em ensaios de exigências nutricionais.

Os enfoques clássicos herdados da agronomia de leguminosas temperadas predominaram por algum ternpo de maneira repetitiva na mesma seqüencia: correção de $\mathrm{pH}$ próximo a 6, adição de $P$ e $K$, de acordo com a análise do solo; o Ca e o $\mathrm{Mg}$ estariam disponíveis pelo uso do calcärio dolomítico e o $S$ se acrescentava naturalmente via superfosfato simples. Os micros (Mo, $\mathrm{Cu}, \mathrm{Zn}, \mathrm{Fe}$, B) foram melhor estudados em cas as de vegetação.

A triagem dos problemas de nutrição $x$ solos $x$ leguminosas era feita em ensaios exploratórios de adição ou subtração, ocasião em que se acompanhava também o desempenho de cepas selecionadas de rizóbio. Essa metodologia, com as devidas atualizaçōes, é empregada atualmente em alguns centros de pesquisas.

Em paralelo, muitos ensaios de nutrição mineral permitiram identificar exigencias específicas de várias leguminosas.

Grandes avanços foram obtidos por esses trēs níveis de abordagem: exigencias nutricionais individuais, interaçöes leguminosas/solo/fertilizantes - mais micros e parcelas de campo. 
Dada a carência generalizada de nossos solos em $P$, - primeiro nutriente limitante para o crescimento dos pastos, principalmente da leguminosa e o microssimbionte, o rizóbio, o "projeto leguminosa" esbarrava com o alto custo do fertilizante fosfatado. A abertura se faria com a participação dos pesquisadores envolvidos na coleta e introdução de plantas. 0 exame dos vários ecossistemas, sub-ecossistemas e nichos ecológicos passou a revelar a existência de plantas que conseguem pro duzir satisfatoriamente em solos com baixos niveis de $P$, além de serem resistentes à presença do Al tóxico e acidez elevada.

Surge assim a possibilidade da introdução da leguminosa com um mínimo de insumos. Essa conceituação fica bem clara em Schultze-Kraft ao afirmar "nosso prin cípio básico foi o de coletar plantas forrageiras nōs habitats das savanas, em situações ambientais semelhantes, para usá-las como introduções cruas, sem qualquer seleção genética" (60).

Outro acontecimento de relevância transcedental para o estudo das pastagens brasileiras foi a criação da EMBRAPA e sua íntima colaboração técnico-científica com o CIAT - Centro Internacional de Agricultura Tropical, situado em Cali, na Colômbia. Os projetos de produção de pastos destas entidades de pesquisa, especialmente no que toca à coleta, introdução e avaliação - no campo e com animais - de plantas forrageiras, vêm apresentando progressivamente resultados da maior importância para a pecuária no trópico/subtrópico das Américas do Sul e Central.

Programas de melhoramento só seriam possíveis quando se dispusesse de abundância de plantas coletadas de cada gēnero e espécies para assegurar ampla variabilidade indispensável aos trabalhos de genética. Al guns gêneros como Stylosanthes $j a \bar{a}$ dispóem de grandes $i \underline{n}$ troduçōes, obtidas principalmente em coletas levadas a efeito nos trópicos/subtrópicos das Américas. Diferentes gêneros como Centrosema, Galactia, Arachis, iesmodium, etc. têm sido enriquecidos com coletas extensas 
com a mesma finalidade de selecionar as espécies "já prontas" para aplicação direta nos pastos, além de propiciar variabilidade suficiente para futuros cruzamentos genéticos.

Do ponto de vista do manejo das leguminosas trepadoras e eretas, muitos estudos têm sido conduzidos para esclarecer sua morfo-fisiologia, mormente quando relacionada à eliminação dos pontos de crescimento por diferentes pressões de pastejo. A mesma problemática se relaciona com as espécies rasteiras, com dispositivos próprios de defesa da ação da desfolha pelo animal.

Não menos importante e, até certo ponto, de difícil solução, tem sido conseguir indices aceitáveis de sociabilidade entre o capim tropical, de metabolismo $\mathrm{C}_{4}$, e a leguminosa $\mathrm{C}_{3}$. Técnicas de adubação diferenciada para capim e leguminosa semeados separadamente em linhas, apresentam resultados animadores. Semeadura an tecipada da leguminosa permite assegurar estande mais uniforme na consorciação. Inclusão da leguminosa em pasto jä estabelecido de capim, mediante tratamentos de superfície (corte, gradeação, adubação fosfatada, etc.) seguidos de aplicações de $P$ de manutenção, etc., e outras técnicas têm sido experimentadas em muitos centros de pesquisa no país. Em alguns estágios mais avançados procura-se verificar os níveis de lotação animal mais favoráveis à manutenção do consórcio capim/leguminosa.

Resultados de ganho de peso vivo com bovinos em pastagens mistas adubadas com $\mathrm{P} \mathrm{K} \mathrm{S} \mathrm{Ca} \mathrm{Mg,} \mathrm{usando-se}$ diferentes capins e leguminosas, em experimentos com du ração superior a 2 anos, revelam em mëdia $329 \mathrm{~kg}$ de ganhos de peso vivo por hectare/ano, sem onerar o sistema com os elevados custos do nitrogênio (53). E de se acreditar que essa tecnologia não se representa substancialmente na prática por falta de espírito empresarial no âmbito de pecuária nacional.

Dentre as grandes conquistas de adaptação ecológica de leguminosas forrageiras, caberia destacar a 
soja perene (Neonotonia wightii) nos climas mais amenos em solos de média a boa fertilidade; o cudzú tropical (Pueraria phaseoloides), principalmente na Região Amazônica, onde foi inicialmente introduzido como cobertura das plantações da "árvore da borracha", o calopogônio (Calopogonium mucunoides) que vem penetrando espontaneamente em vários nichos ecológicos de pastos sem interferência de tecnologia; alēm do cornichão (Lotus comiculatus cv. São Gabriel) de ampla aceitação nos es tados sulinos bem como a já tradicional "alfafa criou1a" (Medicago sativa) com desempenho sempre superior ao das outras cultivares importadas (34). Outras espécies - G. striata e Stylosanthes -, ambas com duas cultivares, jā mencionadas, além de novas liberações como a cv. Guatā do Macroty Zoma axizzare e algumas mais em vias de lançamento na espēcie Trifolium repens, Centrosema pubescens, Leucaena leucocephala, Arachis, Desmodium ovalifolium, etc., ampliam as opçoes aos usuārios.

A disponibilidade de fosfatos (1.s.), mesmo que usados sob o critério de "insumos minimos" por leguminosas com melhor capacidade de utilizą̧ão do $P$, parece determinar o sucesso da sua implantação nos pastos tropicais brasileiros, mormente os localizados nos solos de cerrados.

Apreciāveis progressos vêm sendo observados, tanto nos cultivos estremes de pastos de gramíneas, como em associação com leguminosas, no sistema de rotação pasto/cultura. Razoável soma de experimentos tem sido conduzida nesse sentido para esclarecer a melhor seqüencia e intervalo de tempo para a implantação do pasto em alternáncia com os cultivos anuais $(70,67,32$, $19,27)$.

Os resíduos dos adubos deixados nas plantações de cereais elevam, obviamente, a fertilidade do solo, mormente quando considerado após a plantação de leguminosa, p.ex., soja para grãos. A maior duração e produtividade do pasto misto depende contudo de uma política própria de fertilizantes a fim de exaltar a eficiência 
do sistema simbiótico fornecedor de $\mathrm{N}$ para aumentar os ganhos de peso vivo, lá ou leite, por ärea unitäria e por animal.

A pesquisa discute e experimenta intensamente sobre o problema do $P$, e se preocupa particularmente quan do considerado em termos de 170 milhões de hectares de pastos existentes atualmente no país. Os estudos se processam em escala continental e as possibilidades para a América Latina são promissoras, seja por uma razoável disponibilidade de jazidas de fosfatos ou ainda em resultado de coleta de leguminosas que se adaptaram milenarmente à extração de $P$ em solos pobres, de melhor aproveitamento, de fontes menos solúveis de fósforo $(27,11,30,51,59,68,76)$.

\section{FERTILIZANTE NITROGENADO}

A primeira fábrica brasileira de fertilizante nitrogenado foi construída em Cubatão, SP e, sua produção inicial em 1958 alcançou $450 \mathrm{mil}$ toneladas de nitrocálcio, correspondendo a 99.000 ton. do elemento(*).

A produção atual de nitrogênio no país atende às necessidades de nossa agricultura, sem precisar de importação. Não se incluem aí, obviamente, as pastagens, pelo simples fato de não ser prätica corrente entre nós, o emprego de nitrogênio na exploração pecuária.

O $N$ produzido na indústria nacional atende $a$ agricultura permanente $\left(11.10^{6} \mathrm{ha}\right)$ e anual $\left(42.10^{6} \mathrm{ha}\right)$, num total aproximado de 53 mi thões de hectares. No caso de se admitir o emprego de nitrogênio nas pastagens como prätica económica, seria necessário aumentar em mais de cem por cento a disponibilidade do elemento fer tilizante com vistas aos 64 milhões de hectares

(*) albuquerque, C. (Ultrafertil S/A Indūstria e Comércio de Fertilizantes, São Paulo). Comunicação pessoal, 1988. 
plantados (26) com gramíneas forrageiras em território brasileiro.

Qualquer novo aumento na produção de fertilizantes estarā destinado, preferencialmente, às lavouras anuais ou permanentes cujas áreas de plantio têm sido constantemente ampliadas. Se os custos dos insumos devidos aos fertilizantes apresentam retornos compensadores na agricultura, o mesmo não pode ser dito para a pecuária de corte cuja rentabilidade é muito menor.

Essa problemática de natureza econômica preocupa os estudiosos desde longa data. 0 uso de $\mathrm{N}$ fertilizante para exaltar a produção dos pastos constitui uma tec nologia bem estudada e de fácil aplicação prática (75). Dois fatores relevantes, contudo, dificultam sua efetivação: o custo elevado e o fato de não haver disponibilidade do produto, mesmo que se limitassem às invernadas do SE, p.ex..

A solução a ser encontrada, como vem ocorrendo em outros países tropicais, parece estar ligada ao uso de leguminosas/rizóbios. A fixação biológica de $\mathrm{N}$ atmos férico tem sido obtida experimentalmente no país, em níveis variáveis de 50 a $200 \mathrm{~kg} \cdot \mathrm{ha}^{-1} \cdot$ ano $^{-1}$. Dentre os resultados de ganho de peso vivo por hectare, a leguminosa, em média, contribui com o correspondente a $70 \%$ atribuído ao nitrogênio - cerca de $100 \mathrm{~kg} \cdot \mathrm{ha}^{-1} \cdot$ ano $^{-1}(53)$.

Essa tese ganha progressivamente os Institutos, Universidades e outros Centros de Pesquisa no país. No entanto, coletas de leguminosas são ainda escassas além do número de melhoristas/geneticistas envolvidos com a obtenção do nitrogênio biológico ser muito reduzido. E fato reconhecido entre os pesquisadores que muitas das cultivares de leguminosas preconizadas para o cultivo de pastos mistos, são as mesmas de norte a sul do Brasil e selecionadas em outros países, em condições ecológicas - solo principalmente (58) - bem diferentes. 


\section{RESERVAS FORRAGEIRAS PARA A SECA}

Muito debate jā se travou entre pesquisadores sobre a melhor forma de suprir, mesmo que parcialmente, na quadra desfavorável do ano, as exigências alimentares dos rebanhos. A nivel de granjas leiteiras ou propriedades agrícolas que criam reprodutores, não há dificuldades em se preencher esses 4 a 8 meses de carência forrageira. Silagem, feno cortado e em pé, culturas de inverno, capineiras, canaviais, têm sido estudados há longa data, na totalidade dos centros de pesquisa do país, onde a tecnologia se aprimora continuamente.

A cana-de-açúcar, usada desde os tempos coloniais como forragem para bovinos e eqüideos, é ainda hoje uti lizada para essa finalidade. No ano de 1980 os registros estatísticos informam que cerca de 161 mil hectares de terra são ocupados no Brasil com o plantio de cana-forrageira (4) para ser usada no período de seca. Seu valor forrageiro e limitaçōes, além da necessidade de suplementação, foram revistas recentemente (49), permitindo situar o emprego da cana-de-açúcar no arraçoamento animal.

O emprego da silagem e do feno, como método auxiliar para os invernos secos e frios prevalecentes em ampla faixa do Brasil Central Pecuärio, envolve tecnologias propostas pelos primeiros especialistas estrangeiros contratados como participantes de programas pecuärios brasileiros. Em novembro de 1929 o número 1 , ano 1, da Revista de Indústria Animal ja divulgava longo artigo sobre as práticas da ensilagem (50), construção de silos, etc. onde se notam referências a trabalhos anteriores e se indicam resultados obtidos no campo. De maneira semelhante, as técnicas de fenação são experimentadas com capins e leguminosas desde os primórdios da criação dos centros de pesquisa (57), que ainda hoje investigam novas plantas e processos de cura associados a épocas de corte, formação de prados para feno, sistemas de armazenamento no campo e em abrigos, etc. 
A produçao de conhecimento sobre técnicas de ensilagem tem envolvido enfoques especializados como em química, bioquímica, ingestão, digestibilidade, etc. com capins e leguminosas, além dos tradicionais milho, sorgo e milheto.

A fenação tem tido progressos menos sensíveis, em conseqüencia talvez dos freqüentes riscos devidos à coincidencia da produção forrageira acompanhar uma distribuição muito concentrada das precipitaçôes pluviométricas. Os maiores avanços, do ponto de vista de qualidade do produto e segurança do empreendimento, vêm sendo conseguidos com a fenaçäo das culturas de forrageiras de inverno, irrigadas ou não, como alguns programas da EMBRAPA, em projeto de predução de leite em conf inamento.

Pastos de inverno com espécies temperadas (aveia, centeio, azevém, trevos, ervilhacas, etc.) têm sidó estudados sob värios aspectos, nos climas Aw, $C_{w}, \mathrm{Cf}$, principalmente onde o frio impede o crescimento dos capins $\mathrm{C}_{4}$. Nos estados sulinos existe apreciāvel empenho da pesquisa na exploração dos pastos temporários. Acima da linha do Trópico, com secas de inverno, em sua maior extensão, são investigados processos de fornecimento de ägua, uso das baixadas úmidas, irrigação, épocas mais apropriadas de plantio, etc. Dentro do espírito de uma pecuária moderna, esses conhecimentos tecno lógicos são de fácil implantação nas empresas voltadas à produçào animal.

\section{CACTACEAS}

As cactáceas têm sido estudadas desde longa data como recurso forrageiro para os climas de aridez mais acentuada no denominado Polígono das Secas. A introduçào da "Palma Santa" (resultado do cruzamento de 2 espécies) se deve a H.Lundgren no ano de 1877 , com material proveniente do Texas, E.U.A. (16). Esta mesma fon te informa que em 1905 um fazendeiro A.T. Carvalho, de 
Pernambuco, encontrou em Joazeiro um outro tipo de palma, de melhor aparencia forrageira. Destas duas origens espalhou-se a palma por várias regiões do Nordeste. O melhoramento da cactācea se deu praticamente a partir de quatro tipos principais de palma: Santa, Graü da, Miúda e Redonda.

Muitas pesquisas se envolveram nos tratos agronomicos e utilização da palma, como data de plantio, tipo de mudas ("raquetes" - cladōdios), posição no solo, espaçamento, adubação, corte (intensidade), etc. Embora em menor escala, nestes ūltimos anos, continuam sendo pesquisados diferentes aspectos da exploração da palma.

\section{PASTOS ARBOREOS}

Este setor dos recursos forrageiros tem sido abor dado apenas no aspecto de sua aceitação, época de maior procura pelos animais, partes ediveis (folhas, ramos, vagens, cascas, sementes, etc.), composição bromatológica, etc. A técnica de implantação de fístulas esofageanas tem trazido valiosa contribuição ao reconhecimento das espécies palatáveis, sua participação na dieta ao longo do ano, etc. (64). As informações subjetivas de aceitação das espécies forrageiras vêm sendo progressivamente substituídas ou confirmadas pela pesquisa com animais.

Das arbustivas, a planta que mais se destacou nes tes ültimos anos foi a Leucaena leucocephala, constituindo uma espécie de grandes qualidades com algumas limitações pela mimosina que contém. Estudos de melhoramento e genética têm procurado solucionar esses senões de leguminosa tão promissora.

Outros gêneros de leguminosas têm sido objeto de atenção dos pesquisadores, como Prosopis, principalmente para o Nordeste, Desmanthus, Desmodium, Cassia e Cajanus. No Brasil, tradicionalmente, cerca de 20 espécies de leguminosas e não leguminosas são merecedoras de grande atenção pelos pecuaristas, como Canafístula, 
Camunzé, Sabiā, Jurema, Jucā, Catingueira, Unha-de-Vaca, Turco, Faveiro, Umarizeiro, Feijão Bravo, Pau Branco, Juazeiro, Ficus, Capparis, etc.. o "Feijão Bravo", Cratylia floribunda, p.ex., tem sido, dentre outros, objeto de coleta e seleção, como promissora leguminosa forrageira.

o empenho necessārio da pesquisa envolve, não ape nas a composição bromatológica das folhas ou vagens, mas implica no conhecimento da auto-ecologia das espécies, de seu comportamento em culturas fora do habitat natural, etc. além de seu sistema radicular, porte acessivel ao ramoneio, produção, partes edíveis, capací dade de recuperação, etc. Só a longo prazo se acumulam as informações confiáveis para emprego na pecuária.

\section{SEMENTES DE PLANTAS FORRAGEIRAS}

A expansão das āreas de pastagens plantadas no Brasil tem dependido em larga escala da tecnologia desenvolvida junto aos centros de pesquisa. Grandes projetos foram implantados para superar a baixa qualidade das sementes de plantas forrageiras vendidas no comércio nacional.

Os principais capins "Gordura", "Jaraguä" e "Colonião" eram semeados tradicionalmente na base de 20 a $30 \mathrm{~kg} \cdot \mathrm{ha}^{-1}$ (43) ou mesmo $40 \mathrm{~kg} \cdot \mathrm{ha}^{-1}$ como para o "Gordura" (1). Atualmente, as sementes de gramineas para pasto oferecidas no comércio, de melhor pureza e valor cultural, atingiram níveis bem satisfatórios, não exigindo mais que 2 a $5 \mathrm{~kg} \cdot \mathrm{ha}^{-1}$ para "Colonião", "Gordura", "Jaraguā", "Braquiārias", etc. Algumas firmas beneficiadoras de sementes têm obtido para a braquiária Marandú indice de pureza ao redor de $80-90 \%$ e para o "Colonião" 40-50\%(*), o que situa as sementes desses e de outros capins entre os mais altos níveis internacionais.

(*) SANTOS FILHO, L.F. Comunicação pessoal, 1988. 
Para as leguminosas, ainda de baixa comercialização na faixa tropical/subtropical, padrões de VC\% são também elevados e próximos dos observados em países tro picais desenvolvidos.

Além de toda a tecnologia envolvida na produção, benefício, armazenamento e controle de qualidade das sementes forrageiras tropicais/subtropicais, o setor de processamento foi dos mais absorventes. Houve estreita colaboração entre os órgãos oficiais e as empresas particulares para a obtenção de maquinaria apropriada que garantisse alto índice de pureza das sementes de leguminosas forrageiras e, principalmente, de capins $p$ a ra pasto. Pode-se afirmar que apenas no início dos anos 80 os problemas ligados ao beneficiamento de semen tes forrageiras foram totalmente superados $(*)$.

As associações gramineas/bactérias têm sido intensivamente estudadas quanto ao seu potencial fixador de nitrogênio atmosférico com Beijerinckia e Azotobacter $(22,23)$. Um terceiro sistema associativo $\bar{e}$ revelado em 1976 com $D$. decumbens/Spirillum (21) com melhores perspectivas de fixação do $\mathrm{N}_{2}$. A partir desta última abertura, intensificou-se a pesquisa com essas associaf̧ões no Brasil e em värios outros países, resultando em apreciável bibliografia disponível.

Mesmo considerando-se pequena a fixação de $\mathrm{N}_{2}$ pelo capim/Azospirizlum, atualmente, deve-se levar em conta que pela simplicidade da associação o processo pode beneficiar grandes áreas de pasto em favor dos rebanhos.

\section{MICORRIZA}

0 interesse pelo uso das micorrizas em pastagens, onde esses fungos podem associar-se com os capins e as

(*) SANTOS FILHO, L.F. Comunicação pessoal, 1988. 
leguminosas, vem se amplicando continuamente. As pesquisas se intensificam, especialmente nos solos onde o fósforo nativo é de baixa solubilidade. "O emprego dos fosfatos de rocha na produção de pastos pode ter sua eficiência aumentada com o estudo da inoculação das leguminosas e capins com micorriza" (24).

Os resultados das pesquisas têm se acumulado; no CPAC-EMBRAPA foi registrada a simbiose dos fungos naturais do cerrado com Centrosema pubescens, Brachiaria decumbens e outras, com eficiência medida em nível significativo para a produção de matéria seca e porcentagem de $P$, em casa de vegetação (25).

Aumentando a superficie de contato com o solo as MVA podem atender mais prontamente às necessidades de $P$ pelas leguminosas em virtude da maior extração do ele mento, principalmente quando o sistema de fixação simbiōtica estā operando (77).

os centros de pesquisa vão progressivamente formando equipes para o estudo de micorriza-vesicular-arbuscular, ampliando os recursos tecnológicos para enfrentar o aumento, racionalização e economicidade no estabelecimento e utilização das pastagens.

\section{A EVOLUÇAO DOS REBANHOS E SUA PRODUTIVIDADE}

Alguns resultados do IX Recenseamento Geral-1980 permitem tecer considerações sobre oritmo da evolução dos rebanhos nacionais.

Avaliados, em termos de um período de 30 anos, po de-se ter uma idéia sobre as mudanças ocorridas:

Em algumas empresas pecuárias nacionais existem produtividade bem superior aos resultados contidos no quadro seguinte, em virtude de aplicação de tecnologia avançada. 
E contudo indispensável avaliar a evolução da pecuaria em termos de rebanho nacional para que os números apurados reflitam a nossa realidade.

$\bar{A}$ pesquisa das pastagens pode-se creditar os avan ços quantitativos e qualitativos na produção animal nes sas três décadas (1950-1980). Vê-se que a ampliação das áreas de pastos plantados aumentou 4,29 vezes enquanto o fator de multiplicação para os naturais foi de 1,15 . Esses acréscimos das areas cultivadas com capins envolvem o uso de tecnologia produzida nos centros de pesquisa.

Os resultados assinalados no aumento dos rebanhos bem como na sua produtividade, são devidos principalmente às inovações da pesquisa com plantas forrageiras, além das práticas sanitarias preventivas. A melhoria dos rebanhos, por seleção dos reprodutores, tem encontrado aumento crescente na qualidade dos pastos, permitindo exaltar a performance dos descendentes.

Destaca-se facilmente do Quadro 1 que a lotação animal aumentou de 0,41 para $0,72 \mathrm{cab}^{-h^{-1}}$ ou 1,75 vezes. No mesmo sentido a produção de leite por vaca se ampliou em $86 \%$ no mesmo período.

A constatação pura e simples dos números permite reconhecer uma melhoria sensivel no setor produtivo da pecuária. Considerados, contudo, em relação a outras regiões mais desenvolvidas do mundo, tem-se que admitir padróes ainda muito baixos da exploração pecuária brasileira, não correspondendo ao potencial climático, edá fico, agrostológico (1.s.) e zootécnico da nossa produção animal.

\section{TREINAMENTO POS-GRADUADO}

Ao encerrar este balanço, um tanto geral, da evolução da pesquisa com plantas forrageiras no Brasil, cabe citar o papel relevante do treinamento dos pesquisadores. Cursos os mais diversos são organizados em 
todo o pais nas múltiplas disciplinas pertinentes ao estudo das pastagens. A criação de Cursos de Pós-Graduação em pastos e forrageiras junto às universidades brasileiras a partir da década de 60 constituiu um esforço insubstituível para equipar os centros de pesquisa com conhecimentos atualizados.

Do mesmo modo a conclusão de mestrado ou doutora do no exterior, atendeu à necessidade de especialistas em alguns campos de atuação ainda carentes em nosso meio.

\section{REFERENCIAS BIBLIOGRAFICAS}

(1) AGROCERES. Pastagens me thoradas; alternativas para um rebanho mais produtivo. São Paulo, 1978. $47 \mathrm{p}$.

(2) ALCÂNTARA, P.B.; ALCÂnTARA, V.B.G. \& ALMEIDA, J.E. Estudos de vinte e cinco prováveis variedades de capim elefante (Pennisetum purpureum Schum.). Boletim da Indústria Animal, Nova Odessa, 37(2): 279-302, 1980.

(3) ALENCASTRO, L.F. As origens da escravidão africana. O Estado de São Paulo, São Paulo, 12 de maio de 1988. Suplemento especial - Abolição: 6-7.

(4) ANUĀRIO ESTATÍSTICO DO BRASIL - 1982. Rio de Janeiro, $43: 901,1982$.

(5) ARAOJO, A.A. Pastagens artificiais; especialmente para o Brasil Meridional. São Paulo, Melhoramentos, 1953. 253p.

(6) ARBER, A. The gramineae; a study of cereal, bamboo and grass. Stechert, Wheldon \& Wesley, 1965. 480p.

(7) ARONOVICH, S. \& ROCHA, G.L. Gramíneas e leguminosas forrageiras de importância no Brasil Central Pecuārio. Informe Agropecuärio, Belo Horizonte, 
$11(132): 3-13,1985$.

(8) ARONOVICH, S.; FARIA, E.V. \& DUSI, G.A. O uso de concentrados na alimentação de vacas leiteiras em boas pastagens de capim pangola. II- Resultados de inverno. Pesquisa Agropecuária BrasiZeira. Série Zootecnica, Rio de Janeiro, 7:67$70,1972$.

(9) ARONOVICH, S.; CORREA, A.N.S.; FARIA, E.V.; DUSI, G.A. \& NUNES, P.R. O uso de concentrados na alimentação de vacas leiteiras em boas pastagens de capim pangola. I- Resultados de verão. In: CONGRESSO INTERNACIONAL DE PASTAGENS, 9., São Paulo. São Paulo, 1965. p.919-21.

(10) AZEVEDo, L.G. Tipos de vegetação. In: ATlAS do Brasil Geral e Regional. Rio de Janeiro, IBGE, 1959. p.511-20.

(11) BARBOSA FILHO, M.P. Utilização de fosfatos naturais em solos de cerrado. Informagões Agronomicas, Piracicaba, 28:1-4, 1984.

(12) BRITO, S. Dicionário abreviado de plantas forrageiras. In: ALMANAQUE Agrícola Brasileiro. São Paulo, 1922. p.211-51.

(13) BURTON, G.W. Registration of coast-cross. 1- Bermuda grass (Reg. no 9). Crop Science, Madison, $11: 12-125,1972$.

(14) CAMARGO FILHO, W.P.; CAMARGO, A.M.M.P.; CHALITA, M.A.C.; PIVA, L.H.C. Area de pastagens regionais; composição e participação por variedade de gramínea no Estado de São Paulo. São Paulo, Secretaria de Agricultura. Instituto de Economia Agrícola, 1987. 26p.

(15) CAMPELO, A.B. \& DOBEREINER, J. Estudo sobre a inoculação cruzada de algumas leguminosas florestais. Pesquisa Agropecuária Brasileira, Rio de Janeiro, 4:67-72, 1969.

(16) CAMPELo, E.B. \& SOUZA, A.C.de. Emprego das 
cactáceas forrageiras no poligono das secas. Rio de Janeiro, Ministério da Agricultura. Serviço de Informação Agrícola, 1960. 35p. (SIA, n? 845).

(17) CARDoso, R.M. Efeito da adubação da pastagem de capim gordura (Melinis minutiflora Beauv.) sobre o consumo de nutrientes e a produção de lei te. Viçosa, 1977. 61p. (Doutorado - Universi= dade Federal de Viçosa).

(18) CASTRO, M. 0 mecanismo do mercado de escravos. O Estado de São Paulo, São Paulo, 12 de maio de 1988. Suplemento especial - Abolição: 7 .

(19) BOLETIM TECNICO CATI, Campinas, (23):1-17, 1968.

(20) COSTA, N.M. de S.; FERREIRA, M.B.; CURADO, T.F.C. Leguminosas nativas do Estado de Minas Gerais; coleta e avaliação preliminares de alguns gêneros. Belo Horizonte, EPAMIG, 1978. 64p.

(21) DOBEREINER, J. Potential for nitrogen fixation in tropical legumes and grasses. In: DOBEREINER, J.; BURRIS, H.R.; HOLLAENDER, A.; FRANCO, A.A., ed. Limitations and potentials for biological nitrogen fixation in the tropics. New York, Plenum Press, 1978. p.13-24.

(22) DOBEREINER, J. Sobre a ocorrência de Beijerinckia em alguns estados do Brasil. Revista Brasileira de Biologia, Rio de Janeiro, 19:151-60, 1959.

(23) DOBEREINER, J.; DAY, J.M.; DART, P.J. Fixação de nitrogênio na rizosfera de Paspalum notatum e da cana-de-açūcar. Pesquisa Agropecuāria Brasileira. Série Agronomia, Rio de Janeiro, 8(7): 153-57, 1973.

(24) DONALD, C.M. Summative address; two. In: WILSON, J.R., ed. Plant relations in pastures. Melbourne, CSIRO, 1978. p.411-20.

(25) EMBRAPA. Centro de Pesquisa Agropecuária dos Cerra dos. Relatorio Técnico Anual - $1978 / 79$. 
Planaltina, 1980. p.29-65.

(26) FREITAS, L.M.M.de. Alternativas de uso do cerrado. In: SIMPOSIO SOBRE O CERRADO; USO E MANEJo, 5., Brasília, 1979. Brasília, Editerra, 1980. p.281-316.

(27) GHISI, O.M.A.A.; ALCÂNTARA, P.B.; FIGUEIREDO, L.A. de; PERES, R.M.; CUNHA, P.G.da; LEITE, V.B. de o.; CAMILLOTTI, M.R.D. Avaliação agronômica de Galactia striata (Jacq.) Urb. sob dois niveis de adubação em Nova Odessa, SP. Boletim da Indústria Animal, Nova Odessa, 42(1):1-10, 1985.

(28) GodinHo, J.F. Suinocultura; tecnologia moderna, formação de pastagens. São Paulo, Nobel, 1986. $197 p$.

(29) GOEDERT, W.J. \& LOBATO, E. Eficiência agronômica de fosfatos em solo de cerrado. Pesquisa Agropecuäria Brasileira, Brasília, 15(3): 311-8, 1980 .

(30) HITCHCOCK, A.S. Manual of the grasses of the United States. Washington, USDA, 1935. 1040p. (Miscellaneous Publication, n' 200).

(31) HOEFLICH, V.A.; CRUZ, E.R.; PEREIRA, J.; DUQUE, F. F.; TOLLINI, H. Sistema de produção agrícola no cerrado. In: SIMPOSIO SOBRE O CERRADO, 4., Brasilia, 1976. Belo Horizonte, Itatiaia; São Paulo, EDUSP, 1977. p.37-58.

(32) IBGE. Tabulações avançadas do Censo Agropecuārio. In: Recenseamento Geral do Brasil 1980. Rio de Janeiro, 1982. v.2, pt.2.

(33) INSTITUTO DE zOOTECNIA. Trés novas opsões de for rageiras para a pecuäria tropical. Nova Odessa; Brasília, Ministério da Agricultura, s.d.

(34) JACQUES, A.V.A. Forrageiras para a Região Sul. In: CONGRESSO BRASILEIRO DE PASTAGENS, 1 . e SIMPOSIO SOBRE MANEJO DE PASTAGENS, 8., Piracicaba, 1986. Anais. Piracicaba, FEALQ, 1986. 
p. 443-53.

(35) JANK, L.; SAVIDAN, Y.H.; COSTA, J.C.G. Introdução e avaliação do germoplasma de Panicum maximum. In: SIMPÓSIO SOBRE PRODUÇÃO ANIMAL, 3., Campo Grande, 1986. Anais. Campo Grande, Sociedade Brasileira de Zootecnia, 1986. p.65-74.

(36) LOURENÇO, A.J. Estudo comparativo entre três niveis de fertilização nitrogenada e consorciada com leguminosas em pastagens de capim elefante Napier (Pennisetum purpureum Schum.) na determinação da capacidade de suporte. Boletim da Indústria Animal, Nova Odessa, 35(1):69-80, 1978.

(37) LUCCI, C.S.; ROCHA, G.L.; FREITAS, E.N. Produção de leite em regime exclusivo de pastagens de capins fino e napier. Boletim da Indüstria Animal, Nova Odessa, 29(1):45-51, 1972.

(38) LUCCI, C.S.; ROCHA, G.L.; KALIL, E.B. Produção de leite em pastos de capim fino (Brachiaria mutica) e de capim napier (Pennisetum purpureum). Boletim da Indústria Animal, Nova Odessa, 26: 173-80, 1969.

(39) MAGNANINI, A. Aspectos fito-geográficos do Brasil; áreas características no passado e no presente. Revista Brasileira de Geografia, Rio de Janei ro, 23(4):681-90, 1961.

(40) NUTI, P. Controle biológico da cochonilha - Antonina graminis (Maskel1) pelo inimigo natural Neodusmetia sangwani (RAO). Boletim da Indústria Animal, Nova Odessa, 26:255-61, 1969.

(41) OLIVEIRA, E.M.P. Distribuição geogräfica e taxonômica do capim gordura (Melinis minutiflora Beauv.). Piracicaba, 1974. 82p. (MestradoEscola Superior de Agricultura "Luiz de Queiroz"/USP). 
(42) OLIVEIRA DIAS, J.D. Evolução da agricultura brasileira. Arquivos do Instituto de Pesquisas Agronômicas, Recife, 4:17-44, 1945.

(43) OTERo, J.R. Informacões sobre algumas plantas for rageiras. Rio de Janeiro, Ministério da Agri= cultura, 1961. 334p. (Série Didática, no 11).

(44) OTERo, J.R. Notas de uma viagem de estudos aos campos do sul. Rio de Janeiro, Ministério da Agricultura. Serviço de Informaçāo Agrícola, 1941. 53p.

(45) PARDI, M.C. Beef production in Brazil. In: CONGRESSO INTERNACIONAL DE PASTAGENS, 9., São Pau1o, 1966. Anais. São Paulo, Departamento de Produção Animal, 1966. p.49-60.

(46) PARSONS, J.J. The "africanization" of the New World Tropical. Tup. Geogr. Stu., 34:141-53, 1970 .

(47) PARSONS, J.J. Spread of African pasture grasses to the American Tropics. Joumal of Range Monagement, Baltimore, 25(1):12-7, 1972.

(48) PEDREIRA, J.V.S.; MATTOS, H.B.; MELOTTI, L.; CAMPOS JUNIOR, H.M. Estimativas da capacidade de suporte de capins consorciados com leguminosas. Boletim da Indústria Animal, Nova Odessa, 32(2): 281-92, 1975.

(49) PEIXOTO, A.M. A cana-de-açücar como recurso forrageiro. In: CONGRESSO BRASILEIRO DE PASTAGENS, 1. e SIMPOSIO SOBRE MANEJO DE PASTAGENS, 8., Pi racicaba, 1986. Anais. Piracicaba, FEALQ, $198 \overline{6}$. p.17-47.

(50) PIZA, M.de S. Ensilagem. Revista da Indüstria Animal, São Paulo, 1(1):286-90, 1929.

(51) PORZECANSKY, J. Melhoramento de plantas forrageiras alternativas para adaptação a solos tropicais. In: SEMINĀRIO SOBRE NUTRIÇÃO DE PLANTAS 
FORRAGEIRAS EM SOLOS TROPICAIS ACIDOS, Campo Grande, 1979. Anais. Campo Grande, EMBRAPA. Centro de Pesquisa Agropecuária do Gado de Corte, 1979. p.57-66.

(52) PRONAPA/EMBRAPA - Programa Nacional de Pesquisa Agropecuária/Empresa Brasileira de Pesquisa Agropecuäria. Brasília, (8), 1981. $147 \mathrm{p}$.

(53) ROCHA, G.L.; ALCÂNTARA, V.B.G.; ALCÂNTARA, P.B. Animal production from brazilian tropical pastures. In: INTERNAT IONAL GRASSLAND CRONGRESS, 14., Lexington, 1983. Proceedings. Lexington, 1983. p. 771-4.

(54) ROCHA, G.L.; MARTINELLI, D.; CORRÊA, A.; TUNDISI, A.G.A.; LIMA, E.P.; KALIL, E.B. Pastoreio competitivo de gramineas para a produção de carne. Boletim da Indústria Animal, Nova Odessa, 20: 289-96, 1962.

(55) ROCHA, G.L.; LEITÃO FILHO, H.de F.; ANDRADE, J.B.; SHEPHERD, G.J.; LEMIR, J.; GOUVÊA, L. S. K.; TARODA, N.; GIBBS, P.E.; TAMASHIRO, J.; MONTEIRO, R.; ALCÂNTARA, P.B.; BUFARAH, G.; OLIVEIRA, P. R.D.; ALCÂNTARA, V.B.G.; ALME IDA, J.E.; SALGADO, P.R.; PULZ, F.S.; SIGRIST, J.M.M.; FONSECA, T.C.; PAULINO, V.T. Coleta, identificação e distribuição de leguminosas forrageiras tropicais brasileiras. 1- Brasil Central. Boletim da Indüstria Animal, Nova Odessa, 36(2):255-324, 1979.

(56) ROSEVEARE, G.M. The grassland of Latin America. Aberystwyth, Imperial Bureau of Pastures and Field Crops, 1948. 291p. (Bulletin, no 36).

(57) SAMPAIO, B.C.de. Conservação de forragens; a fenação. Revista da Indústria Animal. São Paulo, $2(3): 320-5,1935$.

(58) SĀNCHEZ, P.A. \& ISBELL, R.F. Comparacion entre los suelos de los Tropicos de America Latina y Australia. In: TERGAS, L.E. \& SÃNCHEZ, P.A., ed. 
Producción de pastos en suelos acidos de 208 tropicos. Cali, CIAT, 1979. p.29-58.

(59) SANZONOWICZ, C. \& GOEDERT, W.J. Uso de fosfatos naturais em pastagens. In: SIMPOSIO SOBRE MANEJO DE PASTAGENS, 7., Piracicaba, 1985. Anais. Piracicaba, FEALQ; Brasilia, FINEP, 1985. p. 235-267.

(60) SCHULTZE-KRAFT, R. Tropical pastures program emphasizes low-input technology for the acid soils. Cali, CIAT, 1982. 8p.

(61) SERPA, A.; RIBEIRO, H.; MATTA, H.; LUCAS, E.D.de; MATTOS, S.da C.; ARONOVICH, S. Influência da adubação nitrogenada e de leguminosas sobre a produção de leite no período seco em pastagens de capim pangola. Revista da Sociedade BrasiZeira de Zootecnia, Viçosa, 2(2):227-44, 1973.

(62) SILVA, C.M.M.de S. Avaliação do gênero Cenchrus no CPATSA. In: SIMPÓSIO SOBRE PRODUÇÃO ANIMAL, 3., Campo Grande, 1986. Anais. Campo Grande, Sociedade Brasileira de Zootecnia, 1986. p.5358.

(63) SILVA, F.J.L. \& AGOSTINI, J.A.E. Ocorrência de um híbrido de Brachiaria no Norte Fluminense. In: REUNIÃO ANUAL DA SOCIEDADE BRASILEIRA DE ZOOTECNIA, 15., Belém, 1978. Anais. Belém, Sociedade Brasileira de Zootecnia, 1978. p.257-8.

(64) SIMÃO NETO, M. Composição botânica e qualidade da dieta selecionada em pastagem nativa por novilhos azebuados com fístula esofágica. II. Período de setembro a fevereiro de 1976. Belo Horizonte, 1976. 62p. (Mestrado - Universidade Federal de Minas Gerais).

(65) SOUZA, F.B.; ANDRADE, R.P.; THOMAS, D. Estilosantes cv. Bandeirante, uma leguminosa forrageira para a região dos cerrados. Pesquisa Agropecuá ria Brasileira, Brasilia, 18(3):319-20, 1983. 
(66) SOUZA, F.B.; ANDRADE, R.P.; THOMAS, D. Estilosantes cv. Pioneiro, uma leguminosa forrageira Qara os cerrados. Pesquis $\alpha$ Agropecuária Brasileira, Brasilia, 18(3):321-2, 1983.

(67) SOUZA, R.V. de \& PEREIRA, A.B. Alternativas de uso dos cerrados em áreas recuperadas; experiência do produtor. In: SIMPÓSIO SOBRE 0 CERRADO; USO E MANEJO, 5., Brasília, 1979. Brasília, Editerra, 1980. p.319-29.

(68) SPAIN, J.M. Forage potential of allic soils of the humid lowland tropics of Latin America. In: TROPICAL FORAGES IN LIVESTOCK PRODUCTION SYSTEMS, Madison, 1975. Proceedings. Madison, ASA, 1975. 8p. (ASA Special Publication, 24).

(69) STEENMEIJER, H.P. Coleta e introdução de leguminos as forrageiras. In: ENCONTRO DE TECNICOS DA REGIÃO CENTRO-SUL PARA DISCUSSÃO DE PROBLEMAS RELACIONADOS ȦS LEGUMINOSAS FORRAGEIRAS, 1., Nova Odessa, 1969. Nova Odessa, Centro de $\mathrm{Nu}-$ trição Animal e Pastagens, 1969. p.1-3.

(70) TICIANELLI, S.A. Alternativas de uso do cerrado em äreas de fronteira agrícola. In: SIMPÓSIO SOBRE O CERRADO; USO E MANEJO, 5., Brasília, 1979. Brasilia, Editerra, 1980. p.319-29.

(71) VALLE, C.B.; SAVIDAN, Y.H.; JANK, L.; COSTA, J. C.G.da. Introdução, avaliação e melhoramento de espécies do gênero Brachiaria. In: SIMPOSIO SOBRE PRODUÇÃO ANIMAL, 3., Campo Grande, 1986. Anais. Campo Grande, Sociedade Brasileira de Zootecnia, 1986. p.41-4.

(72) VILARES, J.B. Climatologia zootécnica. IX- Aspectos da produção de carne em certas zonas tro picais. São Paulo, 1949. 32p.

(73) VILELA, D. Efeito da suplementação do farelo de soja e do milho desintegrado com palha e sabugo sobre o consumo e produção de leite por vaca em 
pastagem de capim gordura (Melinis minutiflora Beauv.). Viçosa, 1978. 54p. (M.S.-Universidade Federal de Viçosa).

(74) VILELA, H. Manejo de pastagens em cerrados. In: SIMPOSIO SOBRE MANEJO DE PASTAGENS, 4., Piracicaba, 1977. Anais. Piracicaba, ESALQ, 1977. p. 284-305.

(75) WERNER, J.C. Adubação de pastagens. Boletim Técnico do Instituto de Zootecnia, Nova Odessa, (18) : 1-49, 1984.

(76) WERNER, J.C.; KALIL, E.B.; GOMES, F.P.; PEDREIRA, J.V.S.; ROCHA, G.L.; SARTINI, H. Competição de adubos fosfatados. Boletim da Indüstria Animal, Nova Odessa, 25:139-49, 1968.

(77) ZAMBOLIM, L. \& SIQUEIRA, J.0. Importância e potencial das associaçóes micorrízicas para a agricultura. Documentos EPAMIG, Belo Horizonte, (26): $1-36,1985$. 